$\begin{array}{cc}\text { ACADEMIA ROMÂNĂ } & \text { Rev. Roum. Chim., } \\ \text { 2019, 64(11), 973-980 }\end{array}$

\title{
REGIO-AND STEREOSELECTIVITY OF [3+2] CYCLOADDITION REACTION OF METHACROLEIN WITH DIARYLNITRONES CATALYZED BY CHIRAL RHODIUM COMPLEX ${ }^{* *}$
}

\author{
Madiha DJAHIECHE, ${ }^{\mathrm{a},{ }^{*}}$ Hamza BOUFENAYA ${ }^{\mathrm{a}, \mathrm{b}}$ and Abbes BOUKHARI ${ }^{\mathrm{a}}$ \\ ${ }^{\text {a }}$ Laboratory of Organic Synthesis, Modeling and Optimization of Chemical Processes, \\ Department of Chemistry University Badji Mokhtar Annaba, B.O. 12, 23000, Algeria \\ ${ }^{b}$ Renewable Energy Research Unit in Saharan Environment, UREMS, \\ Renewable Energy Development Center, CDER, 01000, Adrar, Algeria
}

Received November 20, 2018

Stereoselective 1,3-dipolar cycloadditions asymmetric reaction between $\mathrm{C}, \mathrm{N}$-diarylnitrones and methacrolein catalyzed by the aqueous complex $\left[\left(\mathrm{C}_{5} \mathrm{Me}_{5}\right) \mathrm{Rh}\left(\mathrm{DPPP}^{*}\right) .\left(\mathrm{H}_{2} \mathrm{O}\right)\right]\left(\mathrm{SbF}_{6}\right)_{2},(\mathrm{DPPP}=$ bis $1,2-$ diphenylphosphinopropane) at $-20{ }^{\circ} \mathrm{C}$ are described. We have succeeded in synthesizing nitrones described in the literature with good yields, and those, N-phenyl-Cphenylnitrones which are not described in the literature, with appreciable yields. The isoxazolidines formed from the condensation of these nitrones with methacrolein have been found to be new compounds. The resulting endoisoxazolidines are obtained in modest to high regioselectivity and with ee up to $91 \%$.

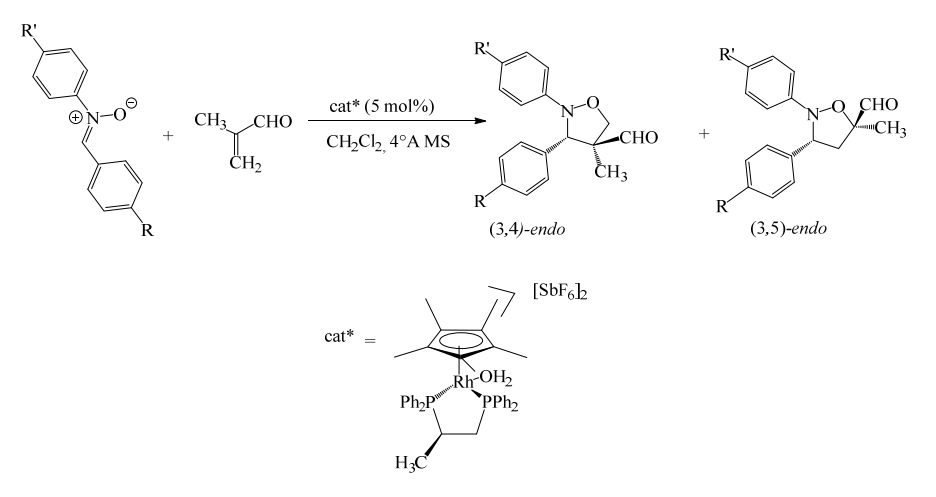

\section{INTRODUCTION}

Asymetric 1,3-dipolar, in particular [2+3] cycloaddition $(1,3-\mathrm{DC})^{1}$ has received a considerable attention in the last year. ${ }^{2}$ One of reason of success, the reaction of nitrones with unsaturated compounds such as olefins is one of the most effective approaches for the preparation of isoxazolidines, ${ }^{1-3}$ and has been widely applied for the synthesis of biologically active compounds ${ }^{4}$. These isoxazolidines undergo ringopening reactions to give 1,3-aminoalcohols, precursors of amino acids, alkaloids or $\beta$-lactams.,

${ }^{5}$ Enantioselective synthesis of isoxazolidines by 1,3-DC can be carried out using chiral Lewis acids containing a transition metal. In view of the enormous potential of this catalysis, it can be prepared isoxazolidines with up to three adjacent stereogenic centers ${ }^{6}$ in a single step ${ }^{7}$. Two types of activation by the chiral catalyst on the dipolarophile have been successfully produced: (a) in the case of 1,2-unsaturated carbonyl compounds they can be motived by coordination with the metal of the catalyst, taking place an interaction between the LUMO of the 1,2-unsaturated carbonyl compound and the HOMO of the nitrone, the process would occur as a normal electronic request (NED). (b) if the interaction takes place between the HOMO of the 1,2-unsaturated carbonyl compound and the LUMO of the nitrone, the process occurred with inverse electron demand (IDE). ${ }^{8}$ Kündig and co-workers ${ }^{6}$ used an iron and

\footnotetext{
* Corresponding author: mdjehieche@gmail.com

${ }^{* *}$ Supplementary information on http: //web.icf.ro/rrch/ or http: //revroum.lew.ro/
} 
ruthenium (Binop-F) catalyst as chiral Lewis acid. Yamada and co-workers ${ }^{9}$ have employed a cationic complex of $\alpha$-ketoiminato cobalt (III) and Kanemasa and co-workers ${ }^{10}$ used chiral DBFOX/Ph-M (II) (M = Ni, Mg or $\mathrm{Zn}$ ) complexes in the 1,3-dipolar asymetric reaction between nitrones and 2-arylacrylaldehyde (Fig.1). Carmona and co-workers ${ }^{11}$ described the first example of a rhodium complex catalytic system giving with perfect stereoselectivity the endo-adducts and with a very good enantiomeric excess. They proved that methacrolein effectively coordinates with ruthenium in one complex with half sandwich structure. The same group have found that the replacement of ruthenium by rhodium accelerates the Diels-Alder reaction of methacrolein and cyclopentadiene. ${ }^{12}$ We envisaged that rhodium complex could give a good selectivity in the 1,3DC between methacrolein and the differently substituted C,N-diarylnitrones.

\section{RESULTS AND DISCUSSION}

\section{Synthesis of nitrones}

C,N-diarylnitrones $\mathbf{3}$ has been synthesized out at room temperature by reaction of aromatic aldehydes $\mathbf{1}$ with nitroarenes $\mathbf{2}$ in the presence of ammonium chloride and zinc powder in a mixture of ethanol / water overnight. ${ }^{13}$
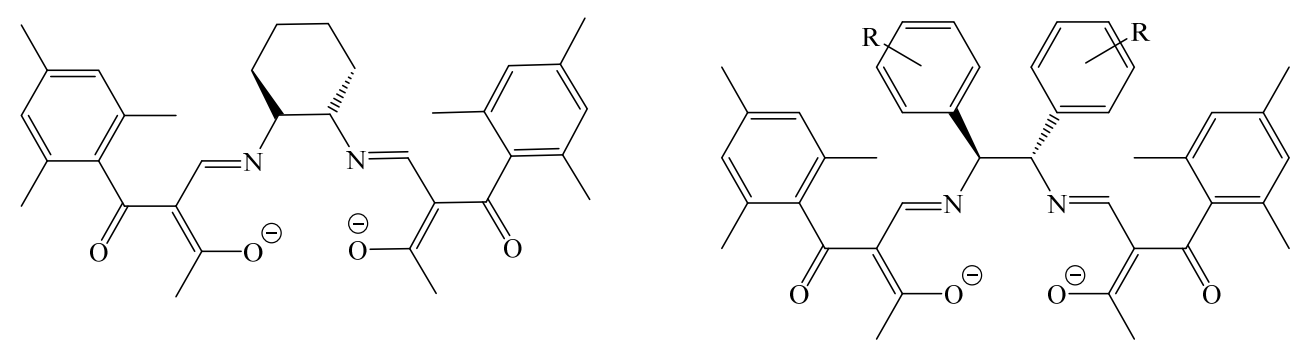

$\beta$-ketoiminatos

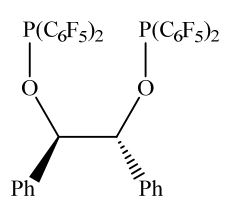

$(1 R, 2 R)$-Binop-F

$(4 R, 4 R)-\mathrm{DBFOX} / \mathrm{Ph}$

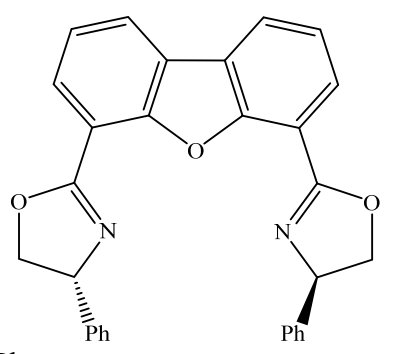

Fig. 1 - Chiral ligands used for the asymmetric 1,3-DC of nitrones with 1, 2-unsaturated aldehydes.<smiles>[R]c1ccc(C=O)cc1</smiles>

1<smiles>[R]c1ccc([N+](=O)[O-])cc1</smiles>

2

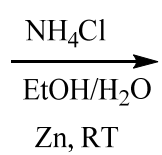

n, RT<smiles>[R]c1ccc(/C=[N+](\[O-])c2ccc([R])cc2)cc1</smiles>

3a: $\mathrm{R}=\mathrm{H}, \mathrm{R}^{\prime}=\mathrm{OMe} ; \quad$ 3d $\mathrm{R}=\mathrm{H}, \mathrm{R}^{\prime}=\mathrm{Br}$

3b: $\mathrm{R}=\mathrm{OMe}, \mathrm{R}^{\prime}=\mathrm{OMe} ; \mathbf{3 e} \mathrm{R}=\mathrm{OMe}, \mathrm{R}^{\prime}=\mathrm{Br}$

3c: $\mathrm{R}=\mathrm{CF}_{3}, \mathrm{R}^{\prime}=\mathrm{OMe} ; \mathbf{3 f} \mathrm{R}=\mathrm{CF}_{3}, \mathrm{R}^{\prime}=\mathrm{Br}$
$\mathrm{R}=\mathrm{H}$ (1a), $\mathrm{OMe}(\mathbf{1 b}), \mathrm{CF}_{3}(\mathbf{1 c})$

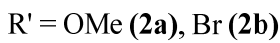

Scheme $1-$ Synthesis of $\mathrm{C}$, 
Table 1

C,N-Diarylnitrones synthesized

\begin{tabular}{lllcc}
\hline Nitrones & $\mathrm{R}$ & $\mathrm{R}^{\prime}$ & $\begin{array}{l}\text { Reported Yields } \\
(\%)\end{array}$ & $\begin{array}{l}\text { Obtained } \\
(\%)^{\mathrm{a}}\end{array}$ \\
\hline $3 \mathrm{a}$ & $\mathrm{H}$ & $\mathrm{OMe}$ & 63 & 52 \\
$3 \mathrm{~b}$ & $\mathrm{OMe}$ & $\mathrm{OMe}$ & 12 & 32 \\
$3 \mathrm{c}$ & $\mathrm{CF}_{3}$ & $\mathrm{OMe}$ & 32 & 47 \\
$3 \mathrm{~d}$ & $\mathrm{H}$ & $\mathrm{Br}$ & 34 & 53 \\
$3 \mathrm{e}$ & $\mathrm{OMe}_{3 \mathrm{f}}$ & $\mathrm{Br}$ & - & 44 \\
\hline
\end{tabular}

${ }^{\text {a }}$ After recrystallization.

${ }^{\mathrm{b}}$ Improved yields.

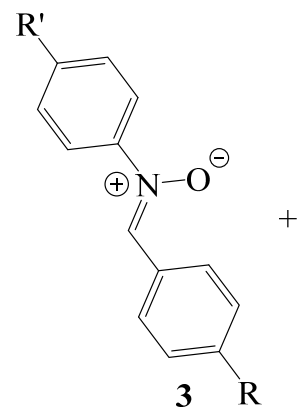<smiles>[R]c1ccc(C2N(c3ccc([R])cc3)OCC2(C)C=O)cc1</smiles>

$(3,4)-$ endo-4<smiles>[R]c1ccc(C2CC(C)(C=O)ON2c2ccc([R])cc2)cc1</smiles>

$(3,5)$-endo-5
Absolute cofiguration not assigned 3b: $\mathrm{R}=\mathrm{OMe}, \mathrm{R}^{\prime}=\mathrm{OMe} \quad$; $\mathbf{3 e}: \mathrm{R}=\mathrm{OMe}, \mathrm{R}^{\prime}=\mathrm{Br}$

3c: $\mathrm{R}=\mathrm{CF}_{3}, \mathrm{R}^{\prime}=\mathrm{OMe} \quad$; $3 f: \mathrm{R}=\mathrm{CF}_{3}, \mathrm{R}^{\prime}=\mathrm{Br}$

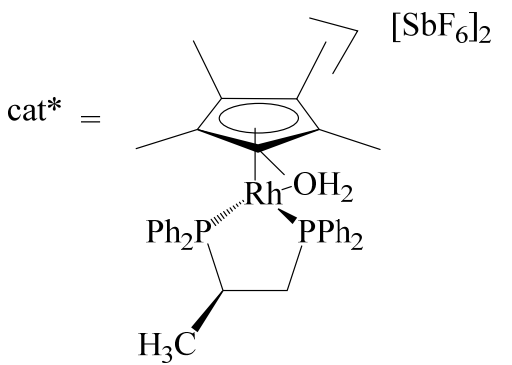

Scheme $2-[2+3]$ cycloaddition of C,N-diarylnitrones with methacrolein catalyzed by rhodium complex.

The multicomponent reaction with the parasubstituted benzaldehyde and the para-substituted nitrobenzene leads to the $\mathrm{C}, \mathrm{N}$-diarylnitrones (Scheme 1). The yields of nitrones $\mathbf{3 b}, \mathbf{3} \mathbf{c}$ and $\mathbf{3 d}$ have been improved while the nitrones $\mathbf{3 e}$ and $\mathbf{3 f}$ which we have prepared are not described in the literature $^{14}$ (Table 1), Apart from the product 3a whose performance in the literature is greater than the one we have synthesized, the other products 3b, 3c and 3d have their yields which are significantly higher than those already described in the literature. ${ }^{14}$

The synthesized nitrones were allowed to react with methacrolein at $-20{ }^{\circ} \mathrm{C}$ in dichoromethane for $20 \mathrm{~h}$ in the presence of $5 \mathrm{~mol} \%$ of the catalyst rhodium complex $(S, R) \quad\left[\left(\mathrm{C}_{5} \mathrm{Me}_{5}\right) \mathrm{Rh}(\mathrm{DPPP} *)\right.$.
$\left.\left(\mathrm{H}_{2} \mathrm{O}\right)\right]\left(\mathrm{SbF}_{6}\right)_{2}{ }^{14}$ giving isoxazolidines $\mathbf{4}$ and $\mathbf{5}$ (Scheme 2), the reaction is maintained by thermostatic bath. The metal complex must be treated by methacrolein in the presence of molecular sieves $4^{\circ} \mathrm{A}$ prior the addition of nitrones 3 in order to remove the molecule of water, which would be replaced by methacrolein. Under these conditions, the complex formed $\left[\left(\mathrm{C}_{5} \mathrm{Me}_{5}\right)\right.$ $\mathrm{Rh}\left(\mathrm{DPPP}^{*}\right)(\text { methacrolein) }]^{2+}$ is a real catalyst present in the solution. ${ }^{15,16}$

The obtained results are shown in Table 2. The conversion of isoxazolidines was determined by proton NMR spectroscopy. In general, quantitative conversions are obtained after the end of reaction at $-20{ }^{\circ} \mathrm{C}$. Conversions between $82-99 \%$ for C,Ndiarylnitrones 3a, 3d and $\mathbf{3 e}$ were obtained, 
whereas lower yields 31- 46\% for nitrones $3 \mathbf{b}, \mathbf{3 c}$ and $\mathbf{3 f}$. The reaction of nitrone $\mathbf{3 b}$ and $\mathbf{3 e}$ with methacrolein results in a regioselective formation of substituted isoxazolidines 4 on carbon atoms 3 and 4 , whereas in the case of nitrone $\mathbf{3 c}$ and $\mathbf{3 f}$ isoxazolidines 5 with the substituents at 3 and 5 position were mainly formed. In the case of the unsubtituted nitrone 3a and nitrone 3d mixtures of regioisomeric isoxazolidines $\mathbf{4}$ and $\mathbf{5}$ were isolated.

The isoxazolidine structures as well as the regioselectivity were characterized by ${ }^{1} \mathrm{H}$ NMR, ${ }^{13}$ C NMR and spectroscopic techniques 2D NMR (H, COSY, HSQC and NOESY). Consider, the example of compounds $\mathbf{4 a}$ and $\mathbf{5 a}$, which are respectively called $(3,4)$-endo and $(3,5)$-endo. The two hydrogens of carbon 4 of the $(3,5)$-endo isomer copulate with each other and with hydrogen of carbon 3 to give a signal in the shape of a doublet of doublet (dd) for each hydrogen $\delta_{1}=2.03 \mathrm{ppm}\left(J=7.20 \mathrm{~Hz}, J_{\text {gem }}=5.50 \mathrm{~Hz}\right)$ and $\delta_{2}=3.03 \mathrm{ppm}\left(J=7.60 \mathrm{~Hz}, J_{\mathrm{gem}}=4.30 \mathrm{~Hz}\right)$. The proton of carbon 3, on the other hand, gives a triplet at $\delta=4.53 \mathrm{ppm}(J=7.50 \mathrm{~Hz})$. In the same way, the hydrogen of the carbon 5 of isomer $(3,4)$ endo copulates to give a doublet (d) at $\delta_{1}=3.64$ $\operatorname{ppm}(J=8.60 \mathrm{~Hz})$ and $\left.\delta_{2}=4.07 \mathrm{ppm}=8.05 \mathrm{~Hz}\right)$, whereas the hydrogen of carbon 3 appears as a singlet at $\delta_{1}=4.86 \mathrm{ppm}$.

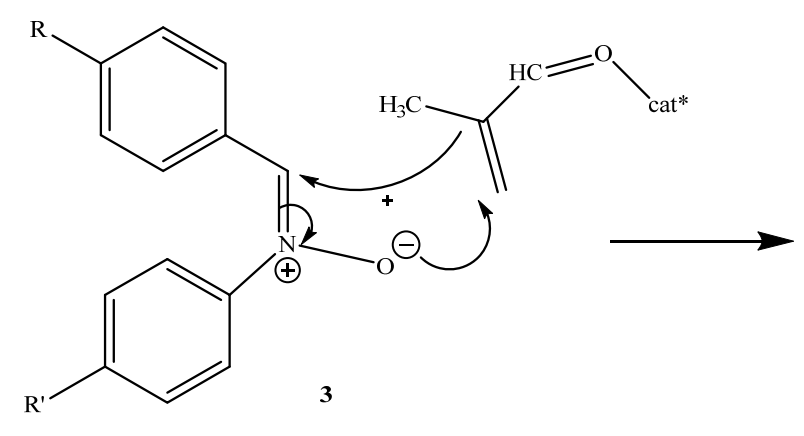<smiles>Cc1ccc([C@@H]2[C@@H](C)CON2c2ccc(Br)cc2)cc1</smiles>

(3, 4)- endo

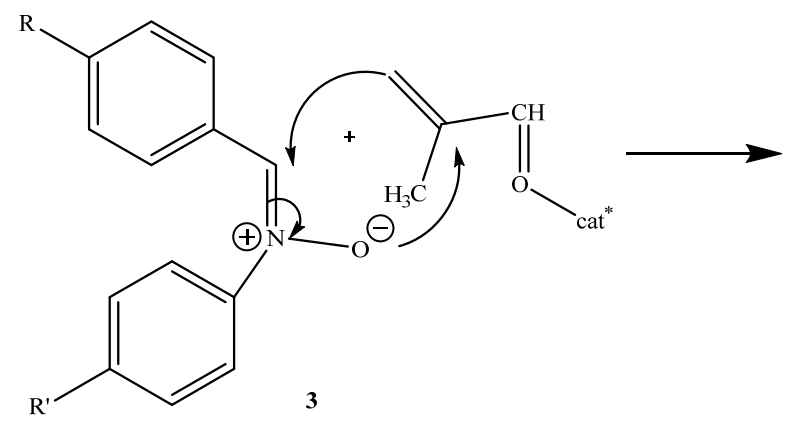<smiles>[R]c1ccc([C@@H]2C[C@](C)(C=O)ON2c2ccc([R])cc2)cc1</smiles>

$(3,5)$-endo
The correlation H, H-COSY of carbon-4 for (3.5)- endo and a correlation of hydrogens with same carbon that are shown in HMQC indicate that these protons are not equivalent and are therefore diastereotopic. This case is observed for all isoxazolidine compounds. Stereoselectivity was determined by the NOESY 2D effect. This phenomenon represents the principal spatial proximity between protons of methyl group placed in the 4 or 5 positions in the heterocyclic compound with the proton located on the carbon-3 (Fig. 2). The reactions occur with perfect stereoselectivity endo. The absolute configuration of cycloadducts as was determined by DRX by Carmona and coworkers. ${ }^{15}$

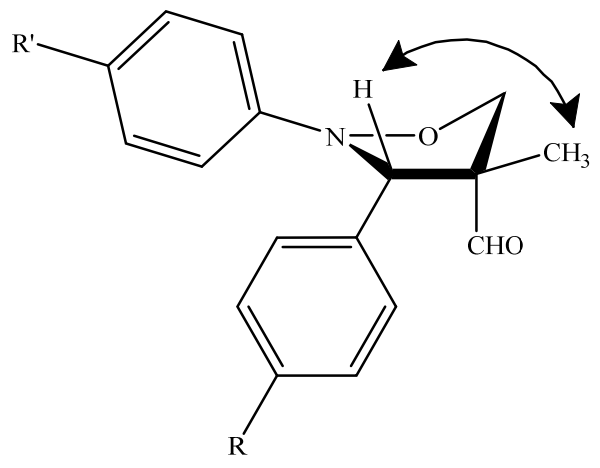

Fig. 2 - NOE for endo-4. 
The formation of isoxazolidines $(3,4)$-endo-4a, $4 \mathbf{b}$ and $4 \mathbf{e}$ is explained by mesomeric effect of the donor substituent at the para-position (OMe and $\mathrm{Br}$ ) on the $\mathrm{N}$-aryl radical of the corresponding nitrones. On the other hand, in the case of compounds $\mathbf{5 c}$ and $\mathbf{5 f}$, isoxazolidines $(3,5)$-endo, the electron-with drawing group $\left(\mathrm{CF}_{3}\right)$ on the $\mathrm{C}$ phenyl radical of the starting nitrones control the formation of the major regioisomeric isoxazolidine. The diastereoisomers $(3,5)$ and $(3,4)$ of compounds $4 \mathbf{d}$ and $\mathbf{5 d}$ are practically obtained in the same proportion, this may be due to the bromine atom group which is donor $(+M)$ and acceptor $(-\mathrm{I})$, placed in the $p$-position on the $N$ phenyl radical.
We have proposed a simultaneous attack in the condensation of nitrones with methacrolein-cat ${ }^{*}$ which shows in Scheme 3.

As shown in Scheme 4, a plausible catalytic cycle to explain the formation of regioisomeric isoxazolidines with rhodium catalyst and nitrones $\mathbf{3}$ by formation of intermediates $\mathbf{A}$ and $\mathbf{B} .{ }^{12}$

The enantioselectivity of the synthesized isoxazolidines is determined by calculating the enantiomeric excess $(\boldsymbol{e} e)$ for each compound from its H-NMR spectrum. For this propose, the reaction of isoxazolidines with benzylmethylamine was carried out (Scheme 5), this results in the formation of imines called Schiff bases. ${ }^{17-20}$ The different reactions give us an enantiomeric excess of more than $72 \%$.

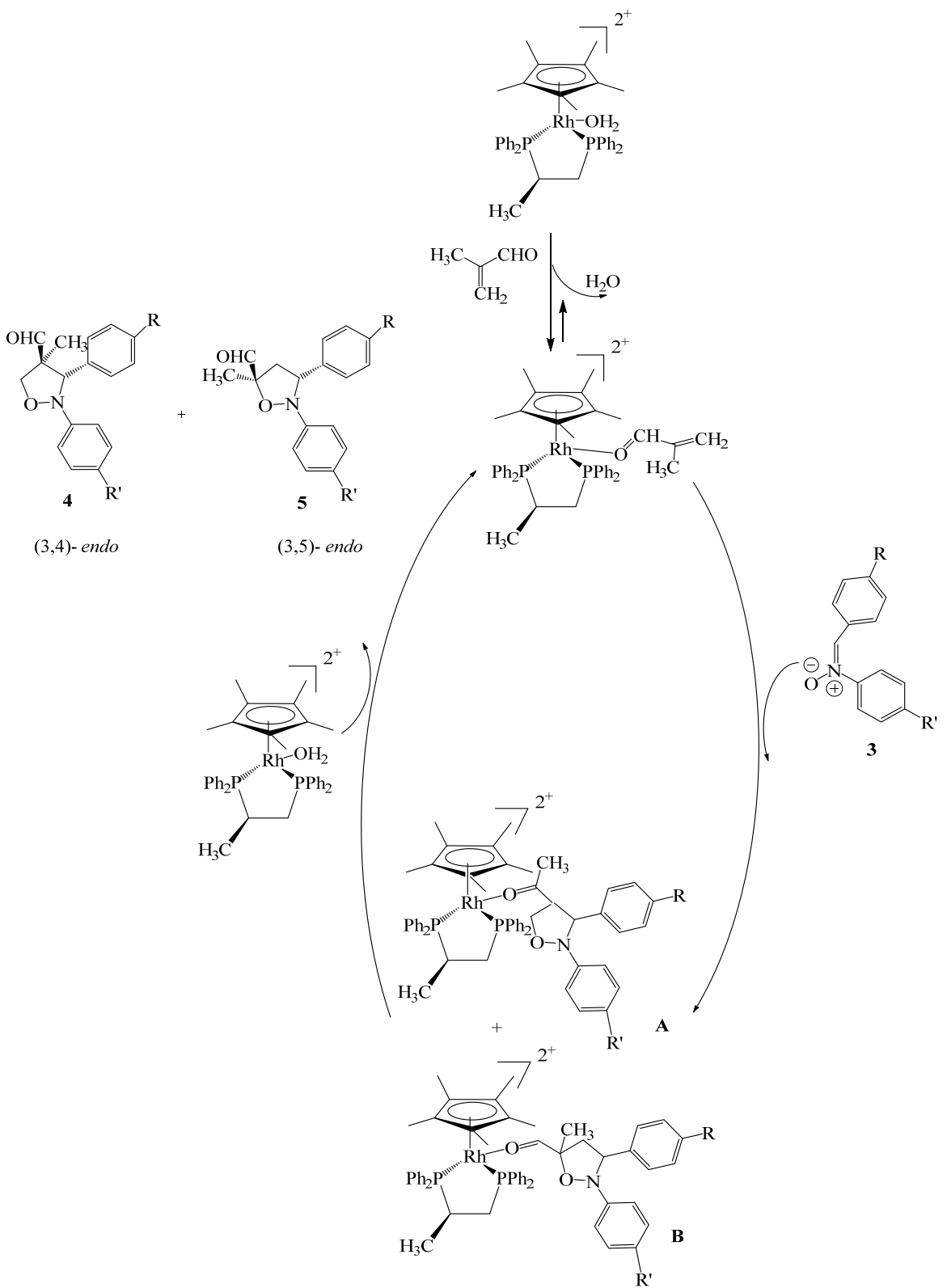

Scheme 4 - Proposed catalytic cycle for the asymmetric [3+2] cycloaddition reaction catalyzed by rhodium complex. 
Table 2

Preparation of isoxazolidines asymmetric [3+2] cycloaddition reaction by $\mathrm{Rh}$ complex

\begin{tabular}{llccc}
\hline Entry & Nitrones & Yield (\%) & endo-4 /endo-5 & $\begin{array}{l}\text { ee(\%) } \\
4 / 5^{\mathrm{a}}\end{array}$ \\
\hline 1 & & & $64 / 36$ & $77 / 84$ \\
2 & $3 \mathrm{a}$ & 84 & $94 / 06$ & $85 / 85$ \\
3 & 3b & 44 & $12 / 88$ & $-/ 79$ \\
4 & $3 \mathrm{c}$ & 31 & $47 / 53$ & $88 / 73$ \\
5 & $3 \mathrm{~d}$ & 99 & $93 / 07$ & $91 / 80$ \\
6 & $3 \mathrm{e}$ & 82 & $05 / 95$ & $-/ 72$ \\
\hline
\end{tabular}

ee was determined by integration of ${ }^{1} \mathrm{H}$ NMR signals after in situ formation of diastereomeric imine with (S)-(-) $\alpha$-methylbenzylamine.

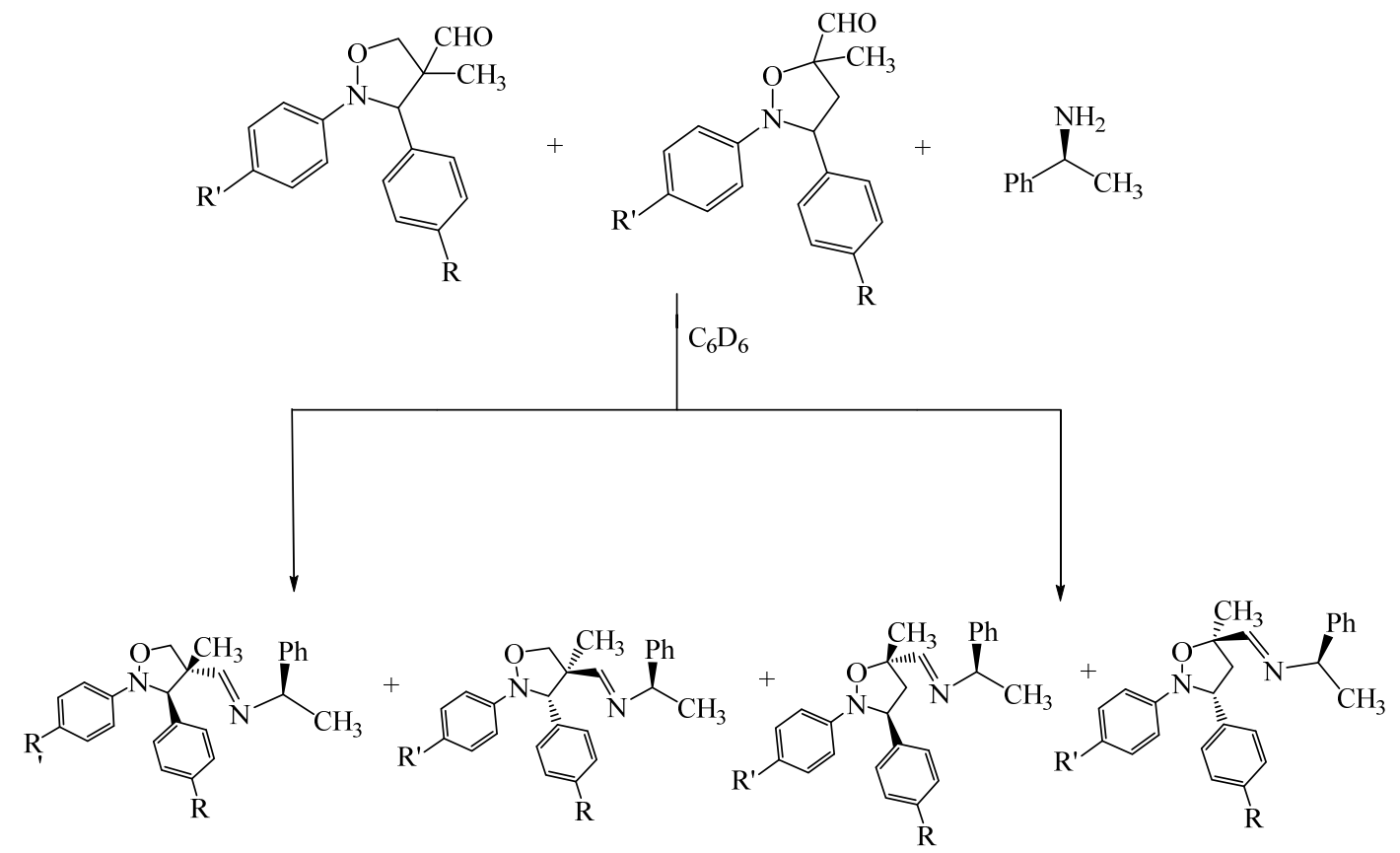

Scheme 5 - Derivatization of $(3,4)$ and $(3,5)$ isoxazolidines.

\section{EXPERIMENTAL}

\section{General}

The synthesis the isoxazolidines was carried under argon. Thin-Layer Chromatography (TLC) was done on plates coated with Merck $60 \mathrm{~F}_{254}$ silica gel and column chromatography was performed on silica gel 400 meshes. The solvents used to form the mobile phases are ethyl acetate and hexane (3/7 Nuclear magnetic resonance spectra ${ }^{1} \mathrm{H}$ and ${ }^{13} \mathrm{C}$ NMR were recorded on a Bruker AV- $300(75 \mathrm{MHz})$ or a Bruker AV- $500(126$ $\mathrm{MHz})$ in chloroform- $d\left(\mathrm{CDCl}_{3}\right)$ or benzene- $d\left(\mathrm{C}_{6} \mathrm{D}_{6}\right)$ solutions and assignments were made by COSY and HSQC experiments. Chemical shifts $(\delta)$ for the proton and carbon nuclear magnetic resonance are expressed in parts per million $(\mathrm{ppm})$, coupling constant $(J)$ values were given in Hertz $(\mathrm{Hz})$. The conventional abbreviations used for description of the spectra are as follows: s: singlet, d: doublet, t: triplet, $\mathrm{m}$ : multiplet, and dd doublet of doublets. Elements analyses were performed on a Perkin-Elmer 240B microanalyzer instrument. Melting point were determined on a Büchi Melting Point Machine B-540 apparatus using open capillaries and reported vales are uncorrected. The complex $(S, R)-\left[\left(\mathrm{C}_{5} \mathrm{Me}_{5}\right) \mathrm{Rh}\left(\mathrm{DPPP}^{*}\right)\right.$ $\left.\left(\mathrm{H}_{2} \mathrm{O}\right)\right]\left(\mathrm{SbF}_{6}\right)_{2}$ was prepared using the description in the procedure $^{15}$.

\section{General procedure of $\mathbf{C}, \mathbf{N}$-diarylnitrones formation}

A vigorously stirred mixture of aromatic aldehyde (20 $\mathrm{mmol})$, the nitroarene $(23 \mathrm{mmol}), \mathrm{NH}_{4} \mathrm{Cl}(26 \mathrm{mmol})$, EtOH $(13 \mathrm{~mL})$ and $\mathrm{H}_{2} \mathrm{O}(13 \mathrm{ml})$ was added zinc dust $(90 \%$, $46 \mathrm{mmol}$ ) in small portions during $30 \mathrm{~min}$. After gentle stirring overnight at room temperature, $100 \mathrm{~mL}$ of hexane was added after filtered off, and the resulting filtrate will evaporate. The crude product was recrystallized from hexane. All C,N-diarylnitroneswere obtained as solids.

$N$-(4-methoxyphenyl)- $\alpha$-(4-phenyl)-nitrone (3a)

${ }^{1} \mathrm{H}$ NMR $\left(300 \mathrm{MHz}, \mathrm{CDCl}_{3}\right): \delta=6.9-7.9\left(\mathrm{~m}, 9 \mathrm{H}, \mathrm{H}_{\mathrm{Ar}}\right)$, $3.66\left(\mathrm{~s}, 3 \mathrm{H}, \mathrm{OCH}_{3}\right) ;{ }^{13} \mathrm{C} \mathrm{NMR}\left(300 \mathrm{MHz}, \mathrm{CDCl}_{3}\right): \delta=160-$ $110.5\left(12 \mathrm{C}, \mathrm{C}^{\mathrm{Ar}}\right), 130.1(\mathrm{~s}, \mathrm{CH}=\mathrm{N}), 55\left(\mathrm{~s}, \mathrm{OCH}_{3}\right)$.

$\mathrm{N}$-(4-methoxyphenyl)-a-(4-methoxyphenyl)-nitrone (3b)

${ }^{1} \mathrm{H}$ NMR $\left(300 \mathrm{MHz}, \mathrm{CDCl}_{3}\right): \delta=8.3(\mathrm{~d}, 2 \mathrm{H}, j=8.95 \mathrm{~Hz}$, $\left.\mathrm{H}_{\mathrm{Ar}}\right), 7.62-6.75\left(6 \mathrm{H}, \mathrm{H}_{\mathrm{Ar}}\right), 3.66\left(\mathrm{~s}, 6 \mathrm{H} 2 \mathrm{OCH}_{3}\right) ;{ }^{13} \mathrm{C} \mathrm{NMR}$ $\left(300 \mathrm{MHz}, \mathrm{CDCl}_{3}\right): \delta=161-163\left(12 \mathrm{C}, \mathrm{C}^{\mathrm{Ar}}\right), 120.3(\mathrm{~s}, \mathrm{CH}=\mathrm{N})$, $134-111\left(12 \mathrm{C}, \mathrm{C}^{\mathrm{Ar}}\right), 55\left(\mathrm{~s}, \mathrm{OCH}_{3}\right)$. (3c)

N-(4-methoxyphenyl)-a-(4-trifluoromethylphenyl)-nitrone

${ }^{1} \mathrm{H}$ NMR $\left(300 \mathrm{MHz}, \mathrm{CDCl}_{3}\right): \delta=8.4(\mathrm{~d}, 2 \mathrm{H}, j=8.28 \mathrm{~Hz}$, $\left.\mathrm{H}_{\mathrm{Ar}}\right), 7.55(\mathrm{~s}, 1 \mathrm{H}, \mathrm{HC}=\mathrm{N}), 7.52\left(\mathrm{~m}, 4 \mathrm{H}, \mathrm{H}_{\mathrm{Ar}}\right), 6.55(\mathrm{~d}, 2 \mathrm{H}$, 
$\left.j=6.9 \mathrm{~Hz}, \mathrm{H}_{\mathrm{Ar}}\right), 3.55\left(\mathrm{~s}, 3 \mathrm{H}, \mathrm{OCH}_{3}\right) ;{ }^{13} \mathrm{C} \mathrm{NMR}(300 \mathrm{MHz}$, $\left.\mathrm{CDCl}_{3}\right): \delta=161-163\left(12 \mathrm{C}, \mathrm{C}^{\mathrm{Ar}}\right), 134(\mathrm{~s}, \mathrm{CH}=\mathrm{N}), 55(\mathrm{~s}$, $\left.\mathrm{OCH}_{3}\right) ;{ }^{19} \mathrm{~F}$ NMR $\left(300 \mathrm{MHz}, \mathrm{CDCl}_{3}\right.$,): $\delta=-62 \mathrm{ppm}\left(\mathrm{s}, \mathrm{CF}_{3}\right)$.

\section{$N$-(4-bromophenyl)- $\alpha$-(4-phenyl)-nitrone (3d)}

${ }^{1} \mathrm{H}$ NMR $\left(300 \mathrm{MHz}, \mathrm{CDCl}_{3}\right): \delta=8.1\left(5 \mathrm{H}, \mathrm{H}_{\mathrm{Ar}}\right), 7.51(\mathrm{~s}$, $1 \mathrm{H}, \mathrm{HC}=\mathrm{N}), 7.45\left(4 \mathrm{H}, \mathrm{H}_{\mathrm{Ar}}\right) ;{ }^{13} \mathrm{C}$ NMR $\left(300 \mathrm{MHz}, \mathrm{CDCl}_{3}\right)$ : $\delta=139-115\left(12 \mathrm{C}, \mathrm{C}^{\mathrm{Ar}}\right), 124.8(\mathrm{~s}, \mathrm{CH}=\mathrm{N}) 55\left(\mathrm{~s}, \mathrm{OCH}_{3}\right)$.

\section{N-(4-bromophenyl)-a-(4-methoxyphenyl)-nitrone (3e)}

${ }^{1} \mathrm{H}$ NMR $\left(300 \mathrm{MHz}, \mathrm{CDCl}_{3}\right): \delta 8.30\left(\mathrm{~d}, 2 \mathrm{H}, \mathrm{H}_{\mathrm{Ar}}\right), 7.59(\mathrm{~s}$, $1 \mathrm{H}, \mathrm{HC}=\mathrm{N}), 7.60-7.15\left(\mathrm{~m}, 6 \mathrm{H}, \mathrm{H}_{\mathrm{Ar}}\right), 3.52\left(\mathrm{~s}, 3 \mathrm{H}, \mathrm{OCH}_{3}\right) ;{ }^{13} \mathrm{C}$ NMR (300 MHz, $\left.\mathrm{CDCl}_{3}\right): \delta=76\left(6 \mathrm{C}, \mathrm{C}_{\mathrm{Ar}}\right), 110\left(6 \mathrm{C}, \mathrm{C}_{\mathrm{Ar}}\right), 109$ $(1 \mathrm{C}, \mathrm{CH}=\mathrm{N})$. Analysis: $\mathrm{C}_{14} \mathrm{H}_{12} \mathrm{BrNO}_{2}(306.16)$; Calcd \%: $\mathrm{C}$, $54.92 ; \mathrm{H}, 3.95 ; \mathrm{N}, 4.58$; Found\%: C, 54. 80; H, 3.91; N, 4.62.

\section{$\mathrm{N}$-(4-bromophenyl)-a-(4-trifluorophenyl)-nitrone (3f)}

${ }^{1} \mathrm{H}$ NMR $\left(300 \mathrm{MHz}, \mathrm{CDCl}_{3}\right): \delta=8.00-8.50\left(\mathrm{~m}, 4 \mathrm{H}, \mathrm{H}_{\mathrm{Ar}}\right)$, $7.20(\mathrm{~s}, 1 \mathrm{H}, \mathrm{HC}=\mathrm{N}), 7.35\left(\mathrm{~m}, 4 \mathrm{H}, \mathrm{H}_{\mathrm{Ar}}\right) ;{ }^{13} \mathrm{C} \mathrm{NMR}(300 \mathrm{MHz}$, $\left.\mathrm{CDCl}_{3}\right): \delta=139-110\left(12 \mathrm{C}, \mathrm{C}_{\mathrm{Ar}}\right), 124(\mathrm{~s}, 1 \mathrm{C}, \mathrm{CH}=\mathrm{N}), 55(\mathrm{~s}$, $1 \mathrm{C}, \mathrm{OCH}_{3}$ ). Analysis: $\mathrm{C}_{14} \mathrm{H}_{9} \mathrm{BrF}_{3} \mathrm{NO}$ (344.13); Calcd \%: C, 48.86; H, 2.64; N, 4.07; Found\%: C, 48.90; H, 2.54; N, 3.98.

\section{General procedure for isoxazolidines formation}

$(0.6 \mathrm{mmol}, 5 \mathrm{~mol} \%)$ of the $\mathrm{Rh}$ complex $(S, R)-\left[\left(\mathrm{C}_{5} \mathrm{Me}_{5}\right)\right.$ $\left.\mathrm{Rh}\left(\mathrm{DPPP}^{*}\right)\left(\mathrm{H}_{2} \mathrm{O}\right)\right]\left(\mathrm{SbF}_{6}\right)_{2}$ was dissolved in $3 \mathrm{ml}$ of $\mathrm{CH}_{2} \mathrm{Cl}_{2}$ solution at $-20^{\circ} \mathrm{C}$. $(0.70 \mathrm{~mL}, 8.40 \mathrm{mmol})$ of methacrolein freshly distilled and $(100.0 \mathrm{mg})$ of activated $4 \AA$ molecular sieves were added and the mixture was stirred of $30 \mathrm{~min}$. A solution containing C,N-diarylnitrone $(1.20 \mathrm{mmol})$ in $(3 \mathrm{ml})$ of $\mathrm{CH}_{2} \mathrm{Cl}_{2}$ was added. Leave to agitate at $-20^{\circ} \mathrm{C}$ for $20 \mathrm{~h},(10 \times 2$ $\mathrm{ml}$ ) of hexanes were added. Filter and evaporate. The crude product was purified by column chromatography to keep back a mixture of desired isomers. Regioselectivity was determined on the crude mixture by ${ }^{1} \mathrm{H}$ NMR analysis in $\mathrm{CDCl}_{3}$ or $\mathrm{C}_{6} \mathrm{D}_{6}$. Enantioselectivity was determined (See Table 2).

(3,4)-endo-4-carbaldehyde-2-(4-methoxyphenyl)-4methyl-3-phenylisoxazolidine (4a)

This compound was obtained as oil brown red, $\mathrm{R}_{\mathrm{f}}$ : 0.80 , mp. $225.1-226.1^{\circ} \mathrm{C}$

${ }^{1} \mathrm{H}$ NMR $\left(300 \mathrm{MHz}, \mathrm{CDCl}_{3}\right): \delta=1.28\left(\mathrm{~s}, 3 \mathrm{H}, \mathrm{CH}_{3}\right), 3.73(\mathrm{~s}$, $\left.3 \mathrm{H}, \mathrm{OC}_{3}\right), 3.98\left(\mathrm{~d}, J=9.00 \mathrm{~Hz}, 1 \mathrm{H}, \mathrm{C}_{2}-\mathrm{O}\right), 4.45(\mathrm{~d}$, $\left.J=8.90 \mathrm{~Hz}, 1 \mathrm{H}, \mathrm{CH}_{2}-\mathrm{O}\right), 4.80(\mathrm{~s}, 1 \mathrm{H}, \mathrm{CH}-\mathrm{N}), 6.68-8.39(\mathrm{~m}$, $\left.9 \mathrm{H}, \mathrm{H}_{\mathrm{Ar}}\right), 9.57(\mathrm{~s}, 1 \mathrm{H}, \mathrm{CHO}) ;{ }^{13} \mathrm{C} \mathrm{NMR}\left(75 \mathrm{MHz}, \mathrm{C}_{6} \mathrm{D}_{6}\right)$ : $\delta=15.32\left(\underline{\mathrm{CH}}_{3}\right), 54.67\left(\mathrm{OCH}_{3}\right), 65.64(\underline{\mathrm{C}}-\mathrm{CHO}), 73.05\left(\underline{\mathrm{CH}}_{2-}\right.$ O), 72.70 ( $\mathrm{CH}-\mathrm{N}-\mathrm{O}), 114.08-128.63\left(9 \underline{\mathrm{C}}^{\mathrm{Ar}}\right), 141.06(\underline{\mathrm{C}}-\mathrm{C} \mathrm{H})$, 143.56 ( $\underline{\mathrm{C}}-\mathrm{N}-\mathrm{O}), 155.64\left(\underline{\mathrm{C}}-\mathrm{OCH}_{3}\right), 200.32$ (ㄷO). Analysis: $\mathrm{C}_{18} \mathrm{H}_{19} \mathrm{NO}_{3}$ (297.35); Calcd. \%: C, 72.71; H, 6.44; N, 4.71; Found\%: C, 72.61; H, 6.35; N, 4.82.

\section{(3,4)-endo-4-carbaldehyde-2,3-bis(4-methoxyphenyl)-4-}

\section{methylisoxazolidine (4b)}

This compound was obtained as oil brown, $\mathrm{R}_{\mathrm{f}}$ : $0.73, \mathrm{mp}$. 290.4-291. $4^{\circ} \mathrm{C}$

${ }^{1} \mathrm{H}$ NMR (300 MHz, $\left.\mathrm{C}_{6} \mathrm{D}_{6}\right): \delta=0.75\left(\mathrm{~s}, 3 \mathrm{H}, \mathrm{C}_{3}\right), 3.36(\mathrm{~s}$, $\left.6 \mathrm{H}, 2 \mathrm{xOCH}_{3}\right), 3.70\left(\mathrm{~d}, 1 \mathrm{H}, J=8.80 \mathrm{~Hz}, \mathrm{CH}_{2}-\mathrm{O}\right), 4.12(\mathrm{~d}$, $\left.J=8.80 \mathrm{~Hz}, 1 \mathrm{H}, \mathrm{C}_{2}-\mathrm{O}\right), 4.84$ (s, $\left.1 \mathrm{H}, \mathrm{C} \underline{\mathrm{H}}-\mathrm{N}\right), 6.76-7.33$ (m, $\left.8 \mathrm{H}, \mathrm{H}_{\mathrm{Ar}}\right), 9.37(\mathrm{~s}, 1 \mathrm{H}, \mathrm{C} \underline{\mathrm{HO}}) ;{ }^{13} \mathrm{C} \operatorname{NMR}\left(75 \mathrm{MHz}, \mathrm{C}_{6} \mathrm{D}_{6}\right)$ : $\delta=15.38\left(\mathrm{CH}_{3}\right), 54.52\left(2 \mathrm{xOCH}_{3}\right), 62.50(\mathrm{C}-\mathrm{CHO}), 73.07(\mathrm{CH}-$ $\mathrm{N}), 72.24\left(\underline{\mathrm{CH}}_{2}-\mathrm{O}\right), 114.01-129.29\left(8 \underline{\mathrm{C}}^{\mathrm{Ar}}\right), 132.61(\underline{\mathrm{C}}-\mathrm{CH})$, $143.99 \quad(\underline{\mathrm{C}}-\mathrm{N}-\mathrm{O}), \quad 159.44 \quad\left(2 \mathrm{x} \underline{\mathrm{C}}-\mathrm{OCH}_{3}\right), 200.54 \quad(\underline{\mathrm{C}} \mathrm{HO})$. Analysis: $\mathrm{C}_{19} \mathrm{H}_{21} \mathrm{NO}_{4}$ (327.38); Calcd. \%: C, 69.71; H, 6.46; N, 4.28; Found\%: C, 53.71; H, 6.43; N, 4.32 .

\section{(3,4)-endo-2-(4-bromophenyl)} methyl-3-phenylisoxazolidine (4d)

-4-carbaldehyde -4-

This compound was obtained as oil light brown, $\mathrm{R}_{\mathrm{f}}$ : 0.68 , mp. $265.5-266.5^{\circ} \mathrm{C}$.

${ }^{1} \mathrm{H}$ NMR $\left(300 \mathrm{MHz}, \mathrm{C}_{6} \mathrm{D}_{6}\right): \delta=0.89\left(\mathrm{~s}, 3 \mathrm{H}, \mathrm{CH}_{3}\right), 3.86(\mathrm{~d}$, $\left.1 \mathrm{H}, J=1.20 \mathrm{~Hz}, \underline{\mathrm{C}}_{2} \mathrm{O}\right), 4.41\left(\mathrm{~d}, 1 \mathrm{H}, J=1.10 \mathrm{~Hz}, \mathrm{CH}_{2} \mathrm{O}\right)$, $4.86(1 \mathrm{H}, \mathrm{s}, \mathrm{CH}-\mathrm{N}), 6.80-7.41\left(\mathrm{~m}, 9 \mathrm{H}, \mathrm{H}_{\mathrm{Ar}}\right), 9.61(\mathrm{~s}, 1 \mathrm{H}$, $\mathrm{C} \underline{\mathrm{HO}}) ;{ }^{13} \mathrm{C}$ NMR $\left(75 \mathrm{MHz}, \mathrm{C}_{6} \mathrm{D}_{6}\right): \delta=15.24\left(\underline{\left.\mathrm{CH}_{3}\right)}, 65.69(\underline{\mathrm{C}}-\right.$ CHO), $76.85\left(\underline{\mathrm{CH}}_{2}-\mathrm{O}\right), 77.36(\underline{\mathrm{C}} \mathrm{H}-\mathrm{N}), 116.20$ ( $\left.\underline{\mathrm{C}}-\mathrm{Br}\right), 123.10-$ $132.25\left(10 \mathrm{C}^{\mathrm{Ar}}\right), 201.27(\mathrm{CHO})$. Analysis: $\overline{\mathrm{C}}_{17} \mathrm{H}_{16} \mathrm{BrNO}_{2}$ (346.22); Calcd. \%: C, 58.97; H, 4.66; N, 4.05; Found\%: C, $59.11 ; \mathrm{H}, 4.80 ; \mathrm{N}, 3.88$.

(3,4)-endo-2-(4-bromophenyl)-4-carbaldehyde-4-methyl3-(4-methoxyphenyl) isoxazolidine (4e)

This compound was obtained as oil brown yellow, $\mathrm{R}_{\mathrm{f}}$ : $0.65, \mathrm{mp} .320 .5-321.5^{\circ} \mathrm{C}$.

${ }^{1} \mathrm{H}$ NMR (500 MHz, $\left.\mathrm{CDCl}_{3}\right): \delta=0.86\left(\mathrm{~s}, 3 \mathrm{H}, \mathrm{CH}_{3}\right), 3.80(\mathrm{~s}$, $\left.3 \mathrm{H}, \mathrm{OCH}_{3}\right), 3.95\left(\mathrm{~d}, J=1.20 \mathrm{~Hz}, 1 \mathrm{H}, \mathrm{CH}_{2} \mathrm{O}\right), 4.38(\mathrm{~d}, J=1.20$ $\left.\mathrm{Hz}, 1 \mathrm{H}, \underline{\mathrm{C}}_{2} \mathrm{O}\right), 4.76$ (s, $\left.1 \mathrm{H}, \mathrm{C} \underline{\mathrm{H}}-\mathrm{O}\right), 6.30-8.38\left(\mathrm{~m}, 8 \mathrm{H}, \mathrm{H}_{\mathrm{A}} \mathrm{r}\right)$, $9.63(1 \mathrm{H}, \quad \mathrm{s}, \quad \mathrm{CHO}) ;{ }^{13} \mathrm{C}$ NMR $\left(126 \mathrm{MHz}, \mathrm{C}_{6} \mathrm{D}_{6}\right)$ : $\delta=14.98\left(\underline{\mathrm{CH}}_{3}\right), 57.40\left(\mathrm{O}^{-} \mathrm{H}_{3}\right), 67.64(\underline{\mathrm{C}}-\mathrm{CHO}), 72.75(\underline{\mathrm{CH}}-\mathrm{N}-$ O), $71.30\left(\underline{\mathrm{C}} \mathrm{H}_{2}-\mathrm{O}\right), 114.00-131.63\left({ }^{\mathrm{C}} \underline{\mathrm{C}}^{\mathrm{Ar}}\right), 114.71(\underline{\mathrm{C}}-\mathrm{Br})$,

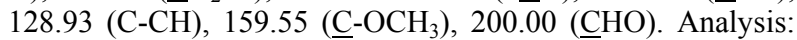
$\mathrm{C}_{18} \mathrm{H}_{18} \mathrm{BrNO}_{3}$ (376.25); Calcd. \%: C, 57.46; H, 4.82; N, 3.72; Found\%: C, 57.99; H, 4.62; N, 3.82 .

(3,5)-endo-5-carbaldehyde-2-(4-methoxyphenyl)-5methyl-3-phenylisoxazolidine (5a)

This compound was obtained as oil brown, $\mathrm{R}_{\mathrm{f}}$ : $0.80, \mathrm{mp}$. 225.1-226. $1{ }^{\circ} \mathrm{C}$.

${ }^{1} \mathrm{H}$ NMR $\left(300 \mathrm{MHz}, \mathrm{CDCl}_{3}\right): \delta=1.52\left(\mathrm{~s}, 3 \mathrm{H}, \mathrm{CH}_{3}\right), 2.34$ $\left(\mathrm{dd}, 1 \mathrm{H},{ }^{2} J=7.20 \mathrm{~Hz} ; 5.50 \mathrm{~Hz}, \mathrm{C}_{2}-\mathrm{C}\right), 3.22(\overline{\mathrm{dd}}, 1 \mathrm{H}$, $\left.{ }^{2} J=7.60 \mathrm{~Hz} ; 4.30 \mathrm{~Hz}, \mathrm{CH}_{2}-\mathrm{C}\right), 3.73\left(\mathrm{~s}, 3 \mathrm{H}, \mathrm{OCH}_{3}\right), 4.63(\mathrm{t}$, $1 \mathrm{H}, J=7.50 \mathrm{~Hz}, \mathrm{CH}-\mathrm{N}), 6.68-8.39\left(\mathrm{~m}, 9 \mathrm{H}, \mathrm{H}_{\mathrm{Ar}}\right), 9.71(\mathrm{~s}, 1 \mathrm{H}$, C브); ${ }^{13} \mathrm{C}$ NMR $\left(75 \mathrm{MHz}, \mathrm{C}_{6} \mathrm{D}_{6}\right): \delta=18.91\left(\underline{\mathrm{CH}}_{3}\right), 46.40$ $\left(\underline{\mathrm{CH}}_{2}\right), 54.67\left(\mathrm{OCH}_{3}\right), 69.20\left(9 \underline{\mathrm{C}}^{\mathrm{Ar}}\right), 86.14(\underline{\mathrm{C}}-\mathrm{CHO}), 114.08-$

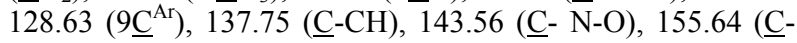
$\left.\mathrm{OCH}_{3}\right), 199.68(\mathrm{CHO})$. Analysis: $\mathrm{C}_{18} \mathrm{H}_{19} \mathrm{NO}_{3}(297.35)$; Calcd. $\%$ : C, 72.71; H, 6.44; N, 4.71; Found\%: C, 72.61; H, 6.35; N, 4.82 .

(3,5)-endo-5-carbaldehyde-2,3-bis(4-methoxyphenyl)-5methylisoxazolidine (5b)

This compound was obtained as oil brown, $\mathrm{R}_{\mathrm{f}}$ : 0.73 , $\mathrm{mp}$. $290.4-291.4^{\circ} \mathrm{C}$

${ }^{1} \mathrm{H}$ NMR $\left(300 \mathrm{MHz}, \mathrm{C}_{6} \mathrm{D}_{6}\right): \delta=1.32\left(\mathrm{~s}, 3 \mathrm{H}, \mathrm{CH}_{3}\right), 2.10(\mathrm{dd}$, $\left.{ }^{2} J=7.00 \mathrm{~Hz} ; 5.22 \mathrm{~Hz}, 1 \mathrm{H}, \mathrm{CH}_{2}-\mathrm{C}\right), 3.05\left(\mathrm{dd},{ }^{2} J=7.90 \mathrm{~Hz}\right.$; $\left.4.80 \mathrm{~Hz}, 1 \mathrm{H}, \mathrm{CH}_{2}-\mathrm{C}\right), 3.38\left(\mathrm{~s}, 6 \mathrm{H}, 2 \mathrm{xOCH}_{3}\right), 4.51(\mathrm{t}, J=7.50$ $\mathrm{Hz}, 1 \mathrm{H}, \mathrm{CH}-\mathrm{N}), 6.76-7.33$ (m, 8H, $\left.\mathrm{H}_{\mathrm{Ar}}\right), 9.67$ (s, 1H, C부); ${ }^{13} \mathrm{C}$ NMR $\left(126 \mathrm{MHz}, \mathrm{C}_{6} \mathrm{D}_{6}\right): \delta=19.09\left(\mathrm{CH}_{3}\right), 46.45\left(\mathrm{CH}_{2}\right)$, $54.52\left(2 \mathrm{xOCH}_{3}\right), 69.03$ ( $\left.\mathrm{CH}-\mathrm{N}-\mathrm{O}\right), 85.90$ ( $\left.\mathrm{C}-\mathrm{CHO}\right), 114.01$ $128.43\left(8 \underline{\mathrm{C}}^{\mathrm{Ar}}\right), 129.29(\mathrm{C}-\mathrm{CH}), 143.49(\underline{\mathrm{C}-\mathrm{N}-\mathrm{O}}), 159.44(2 \times \mathrm{C}-$ $\left.\mathrm{OCH}_{3}\right), 199.95$ (HO). Analysis: $\mathrm{C}_{19} \mathrm{H}_{21} \mathrm{NO}_{4}$ (327.38); Calcd. \%: C, 69.71; H, 6.46; N, 4.28; Found\%: C, 53.71; H, 6. 43; N, 4.32 .

(3,5)-endo-5-carbaldehyde-2-(4-methoxyphenyl)-5methyl-3(4-trifluoromethyl phenylisoxazolidine $(5 \mathrm{c})$

This compound was obtained as oil brown, $\mathrm{R}_{\mathrm{f}}$ : 0.65 , mp. 273.3-274. $3^{\circ} \mathrm{C}$.

${ }^{1} \mathrm{H}$ NMR $\left(300 \mathrm{MHz}, \mathrm{CDCl}_{3}\right): \delta=1.40\left(\mathrm{~s}, 3 \mathrm{H}, \mathrm{CH}_{3}\right), 2.18$ $\left(\mathrm{dd},{ }^{2} J=7.00 \mathrm{~Hz}, 5.30 \mathrm{~Hz}, 1 \mathrm{H}, \mathrm{CH}_{2}-\mathrm{C}\right), 3.16\left(\mathrm{dd},{ }^{2} J=8.00\right.$ $\left.\mathrm{Hz}, 4.70 \mathrm{~Hz}, 1 \mathrm{H}, \mathrm{CH}_{2}-\mathrm{C}\right), 3.79\left(\mathrm{~s}, \overline{3} \mathrm{H}, \mathrm{OCH}_{3}\right), 4.48(\mathrm{t}, 1 \mathrm{H}$, $J=7.50$, CH-N), 6.66-8.44 (m, 8H, $\left.\mathrm{H}_{\mathrm{Ar}}\right), 9.57$ (s, $\left.1 \mathrm{H}, \mathrm{CHO}\right)$; ${ }^{13} \mathrm{C}$ NMR $\left(75 \mathrm{MHz}, \mathrm{C}_{6} \mathrm{D}_{6}\right): \delta=18.38\left(\underline{\mathrm{CH}}_{3}\right), 45.83,\left(\underline{\mathrm{CH}}_{2}\right)$, 
$55.08\left(\mathrm{OCH}_{3}\right), 68.32$ ( $\left.\underline{\mathrm{CH}}-\mathrm{N}-\mathrm{O}\right), 86.44$ ( $\left.\underline{\mathrm{C}}-\mathrm{CHO}\right), 113.90-$ $128.61\left(8 \underline{\mathrm{C}}^{\mathrm{Ar}}\right), 122.88\left(\underline{\mathrm{CF}}_{3}\right), 127.24\left(\underline{\mathrm{C}}-\mathrm{CF}_{3}\right), 143.54(\underline{\mathrm{C}}-\mathrm{N}-\mathrm{O})$, $143.82(\underline{\mathrm{C}}-\mathrm{CH}), 144.93\left(\underline{\mathrm{C}}-\mathrm{OCH}_{3}\right), 200.22(\underline{\mathrm{CHO}})$. Analysis: $\mathrm{C}_{19} \mathrm{H}_{18} \mathrm{~F}_{3} \mathrm{NO}_{3}$ (365.35); Calcd. \%: C, 62.46; $\mathrm{H}, 4.96 ; \mathrm{N}, 3.83$; Found\%: C, 62.59; H, 5.13; N, 3.60.

\section{(3,5)-endo-2-(4-bromophenyl)-5-carbaldehyde-5-methyl-} 3-phenylisoxazolidine $(5 \mathrm{~d})$

This compound was obtained as oil light brown, $\mathrm{R}_{\mathrm{f}}$ : 0.68 , mp. $265.5-266.5^{\circ} \mathrm{C}$.

${ }^{1} \mathrm{H}$ NMR $\left(300 \mathrm{MHz}, \mathrm{C}_{6} \mathrm{D}_{6}\right): \delta=1.51\left(\mathrm{~s}, 3 \mathrm{H}, \mathrm{CH}_{3}\right), 2.28(\mathrm{dd}$, $\left.{ }^{2} J=6.50 \mathrm{~Hz}, 4.30 \mathrm{~Hz}, 1 \mathrm{H}, \underline{\mathrm{CH}}_{2}-\mathrm{C}\right), 3.29\left(\mathrm{dd},{ }^{2} J=8.20 \mathrm{~Hz}\right.$, $\left.4.10 \mathrm{~Hz}, 1 \mathrm{H}, \mathrm{C}_{\underline{H}_{2}}-\mathrm{C}\right), 4.71(\mathrm{t}, J=7.70 \mathrm{~Hz}, 1 \mathrm{H}, \mathrm{CH}-\mathrm{N}), 6.80-$ $7.41\left(9 \mathrm{H}, \mathrm{m}, \overline{\mathrm{H}}_{\mathrm{Ar}}\right), 9.66(1 \mathrm{H}, \mathrm{s}, \mathrm{CHO}) ;{ }^{13} \mathrm{C} \operatorname{NMR}(75 \mathrm{MHz}$, $\left.\mathrm{C}_{6} \mathrm{D}_{6}\right): \delta=18.04\left(\underline{\mathrm{CH}}_{3}\right), 45.33\left(\underline{\mathrm{CH}}_{2}\right), 67.38(\underline{\mathrm{C}} \mathrm{H}-\mathrm{N}-\mathrm{O}), 116.24$ (C-Br), 123.10-132.08 (11C $\left.{ }^{\mathrm{Ar}}\right), 199.97$ ( $\left.\underline{\mathrm{C}} \mathrm{HO}\right)$. Analysis: $\mathrm{C}_{17} \mathrm{H}_{16} \mathrm{NO}_{2} \mathrm{Br}(346.22)$; Calcd. \%: C, 58.97; $\mathrm{H}, 4.66 ; \mathrm{N}, 4.05$; Found\%: C, 59.11; H, 4.80; N, 3.88.

(3,5)-endo-2-(4-bromophenyl)-5-carbaldehyde-5-methyl3-(4-trifluoromethylphenyl) isoxazolidine (5f)

This compound was obtained as solid brown, $\mathrm{R}_{\mathrm{f}}: 0.83, \mathrm{mp}$. 290.9-291.9 ${ }^{\circ} \mathrm{C}$.

${ }^{1} \mathrm{H}$ NMR $\left(300 \mathrm{MHz}, \mathrm{C}_{6} \mathrm{D}_{6}\right): \delta=1.26\left(\mathrm{~s}, 3 \mathrm{H}, \mathrm{CH}_{3}\right), 1.95(\mathrm{dd}$, $\left.{ }^{2} J=6.30 \mathrm{~Hz}, 4.90 \mathrm{~Hz}, 1 \mathrm{H}, \mathrm{CH}_{2}-\mathrm{C}\right), 3.02\left(\mathrm{dd},{ }^{2} J=8.10 \mathrm{~Hz}\right.$, $\left.4.70 \mathrm{~Hz}, 1 \mathrm{H}, \mathrm{CH}_{2}-\mathrm{C}\right), 4.50(\mathrm{t}, J=7.50 \mathrm{~Hz}, 1 \mathrm{H}, \mathrm{C} \underline{H}-\mathrm{N}) 6.62-$ $8.33\left(\mathrm{~m}, 8 \mathrm{H}, \mathrm{H}_{\mathrm{Ar}}\right), 9.51(\mathrm{~s}, 1 \mathrm{H}, \mathrm{CHO}) ;{ }^{13} \mathrm{C} \mathrm{NMR}(75 \mathrm{MHz}$, $\left.\mathrm{C}_{6} \mathrm{D}_{6}\right): \delta=18.89\left(\underline{\mathrm{CH}}_{3}\right), 45.83\left(\underline{\mathrm{CH}}_{2}\right), 68.32(\underline{\mathrm{CH}}-\mathrm{N}-\mathrm{O}), 86.43$ (C-CHO), $117.21(\mathrm{C}-\mathrm{Br}), 122.79\left(\underline{\mathrm{CF}}_{3}\right), 127.22\left(8 \mathrm{C}^{\mathrm{Ar}}\right), 129.45$

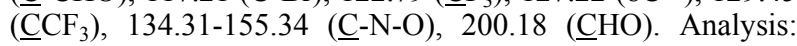
$\mathrm{C}_{18} \mathrm{H}_{15} \mathrm{BrF}_{3} \mathrm{NO}_{2}$ (414.22); Calcd. \%: C, 52.19; H, 3.65; N, 3.38; Found\%: C, 52.31; H, 3.54; N, 3.15.

\section{CONCLUSION}

We have described an efficient synthesis of $\mathrm{C}, \mathrm{N}$-diarylnitrones 3a-f, which were condensed with methacrolein to give isoxazolidines $\mathbf{4 a - f}$ and 5a-f via an asymmetric [3+2] cycloaddition reaction in the presence of a chiral rhodium catalyst $(S, R)\left[\left(\mathrm{C}_{5} \mathrm{Me}_{5}\right) \mathrm{Rh}\left(\mathrm{DPPP}^{*}\right)\left(\mathrm{H}_{2} \mathrm{O}\right)\right]\left(\mathrm{SbF}_{6}\right)_{2}$. The in situ formation of methacrolein complex catalyzed, the formation of endo- isoxazolidines $(3,4)$ and $(3,5)$ with ee up to $91 \%$.

Acknowledgement. We thank DGRSDT (General Direction of Scientific Research Department of Technology of Algeria) for their precious help.

\section{REFERENCES}

1. H. Pellissier, Tetrahedron., 2012, 68, 2197.

2. S. Karlsson and H.-E. Höberg, Org, Prep. Proc. Int., 2001, 33, 103-172.
3. K. V. Gothelf, K. B. Jensen and K. A. Jörgensen, Sci. Prog., 1999, 82, 327-350.

4. M. Frederickson, Tetrahedron., 1997, 53, 403-425.

5. A. Padwa, W. H. Pearson, "Synthetic applications of 1,3Dipolar Cycloaddition Chemistry toward Heterocycles and natural products"; EDS.; Wiley and sons: Hoboken, New Jersey, 2003.

6. F. Viton, G. Bernardinelli and E. P. Künding, J. Am. Chem. Soc., 2002, 124, 4968-49-69.

7. (a) T. Hashimoto and K. Maruoka, Chem. Rev., 2015, 115, 5366-5412; (b) D. Carmona and L. A. Oro, Top. Organomet. Chem., 2011, 34, 09-30; (c) C. Najera, J. M. Sansano, J. M. Yus and J. Braz. Chem. Soc., 2010, 21, 377- 412; (d) L. M. Stanley and M. P. Sibiti, Chem. Rev., 2008, 108, 2887-2902; (e) H. Pellissier, Tetrahedron., 2007, 63, 3235-3285; (f) K. V. Jørgensen, Chem. Rev., 1998, $98,867-883$.

8. J. J. Tufariello and A. Padwa, "In 1, 3-Dipolar Cycloaddition Chemistry" (Ed), Jhon Wiley: New York, Chapter 9, 1984.

9. (a) T. Mita, N. Ohtsuki, T. Ikeno and T. Yamada, Org. Lett., 2002, 4, 2457-2460; (b) N. Ohtsuki, S. Kezuka, Y. Kogami, T. Mita, T. Ashizawa, T. Ikeno and T. Yamada, Bull. Chem. Soc. Jpn., 2003, 76, 2197-2207.

10. M. Shirahase, S. Knemasa and Y. Oderaotosi, Org. Lett., 2004, 6, 4061-4063.

11. D. Carmona, M. P. Lamata, F. Veguri, R. Rodriguez, A. Oro. Luis, A. I. Balana, Ferlando. J. Lhoz, T. Tejero, P. Merino, S. Franco and I. Montesa, J. Am. Chem. Soc., 2004, 126, 2716-2717.

12. D. Carmona, C. Cativiela, S. Elipe, F. J. Lahoz, M. P. Lamata, M. P. López-Ram de Víu, L. A. Oro, C. Vega and F. Viguri. Chem, Commun., 1997, 2351-2352.

13. L. Tian, G.-Y. Xu, Y. Ye and L-Z. Liu, Synthesis., 2003, 1329-1334.

14. M.-C. Lo and G. C. Fu. J. Am. Chem. Soc., 2002, 124, 4572-4573.

15. D. Carmona, C. Cativiela, R. Garcia-Correas, Ferlando. J. Lhoz, M. P Lamata, J. A. López, M. P. López-Ram de Víu, L. A. Oro, E. San José and F. Viguri. Chem, Commun., 1996, 1247-1248.

16. D. Carmona, M. P. Lamata, F. Veguri, R. R. Rodriguez, L. A. Oro, F. J. Lahoz, Ana I. Balana. T. Tejero, P. Merino, J. Am. Chem. Soc., 2005, 127, 13386-13398.

17. A. Boukhari, R. Blida and F. Ismail, C. R. Chimie., 2010, $13,1440-1442$.

18. T. Hyashi, H. Shibata. S. Orita and T. Akitsu, Eur. Chem. Bull., 2012, 249.

19. A. Afkhami, T. Mdrakian, A. Shirzadmehr, M. Tabatabaee and H. Beghri, Sensor, B. Octuators, Chemical., 2012, 174, 237.

20. H. Molaee, M. Moghadam, V. Mirkhani, S. Tangestaninejad, M. M.-P. Baltork. I, B. B. Kajani, R. Kia, Polyhedron., 2018, 1-25. 